\title{
The use of HBV model for flash flood forecasting
}

\author{
M. Kobold ${ }^{1}$ and M. Brilly ${ }^{2}$ \\ ${ }^{1}$ Environmental Agency of the Republic of Slovenia, Vojkova 1b, 1000 Ljubljana, Slovenia \\ ${ }^{2}$ Faculty of Civil and Geodetic Engineering, University of Ljubljana, Jamova 2, 1000 Ljubljana, Slovenia
}

Received: 16 September 2005 - Revised: 23 January 2006 - Accepted: 7 March 2006 - Published: 24 May 2006

\begin{abstract}
The standard conceptual HBV model was originally developed with daily data and is normally operated on daily time step. But many floods in Slovenia are usually flash floods as result of intense frontal precipitation combined with orographic enhancement. Peak discharges are maintained only for hours or even minutes. To use the HBV model for flash flood forecasting, the version of HBV-96 has been applied on the catchment with complex topography with the time step of one hour. The recording raingauges giving hourly values of precipitation have been taken in calibration of the model. The uncertainty of simulated runoff is mainly the result of precipitation uncertainty associated with the mean areal precipitation and is higher for mountainous catchments. Therefore the influence of number of raingauges used to derive the areal precipitation by the method of Thiessen polygons was investigated.

The quantification of hydrological uncertainty has been performed by analysis of sensitivity of the HBV model to error in precipitation input. The results show that an error of $10 \%$ in the amount of precipitation causes an error of $17 \%$ in the peak of flood wave. The polynomial equations showing the relationship between the errors in rainfall amounts and peak discharges were derived for two water stations on the Savinja catchment. Simulated discharges of half-yearly runs demonstrate the applicability of the HBV model for flash flood forecasting using the mesoscale meteorological forecasts of ALADIN/SI model as input precipitation data.
\end{abstract}

\section{Introduction}

Although the processes which generate river floods are well understood, even within small river basins, it is normally possible to incorporate them into flood forecasting procedures

Correspondence to: M. Kobold

(mira.kobold@gov.si) only in a generalised and largely empirical manner because of their spatial and temporal complexity (Smith and Ward, 1998). Many models have been developed for river catchments throughout the world with various degree of complexity, from simple empirical formulae or correlations to the complex mathematical models, representing all phases of the water balance of a river basin (WMO, 1994; Singh, 1995; Beven, 2001). The models were carried out for different purposes as research or operational tool, but only some of them have been found to have a general applicability in flood forecasting. The experiences of the WMO trials (WMO, $1975,1992)$ and experiences of many authors compared different types of models (Askew, 1989; Bell and Moore, 2000; Kokkonen and Jakeman, 2001; Perrin et al., 2001; Job et al., 2002) show that the complex models generally do not give better results than the simpler ones. The selection of the model is therefore not critical to the success of the forecast. But the applicability of models decreases especially in flash flood forecasting.

Flash floods are usually associated with isolated and localised very intense rainfall events occurring in small and medium-sized basins. Peak discharges are maintained only for hours or even minutes. This kind of floods is characteristic for the most of Slovenian rivers. More than two thirds of Slovenian territory is mountainous alpine and hilly areas threatened by heavy rain and flash floods, resulting to landslides and riverbank erosion. The floods occur quite frequently, but mostly and the heaviest in spring and autumn time. The greatest floods usually occur in autumn when cold front passes central Europe, or by passing of Mediterranean cyclone forms in the bay of Genova. The combination of frontal precipitation enhanced by orographic influence plays the most important role in the case of strong events. Rainfall intensities of more than $70 \mathrm{~mm} / \mathrm{h}$ and $240 \mathrm{~mm} /$ day are quite common.

Different types of models are used for flood forecasting in Slovenian hydrological forecasting service (Sušnik and

Published by Copernicus GmbH on behalf of the European Geosciences Union. 


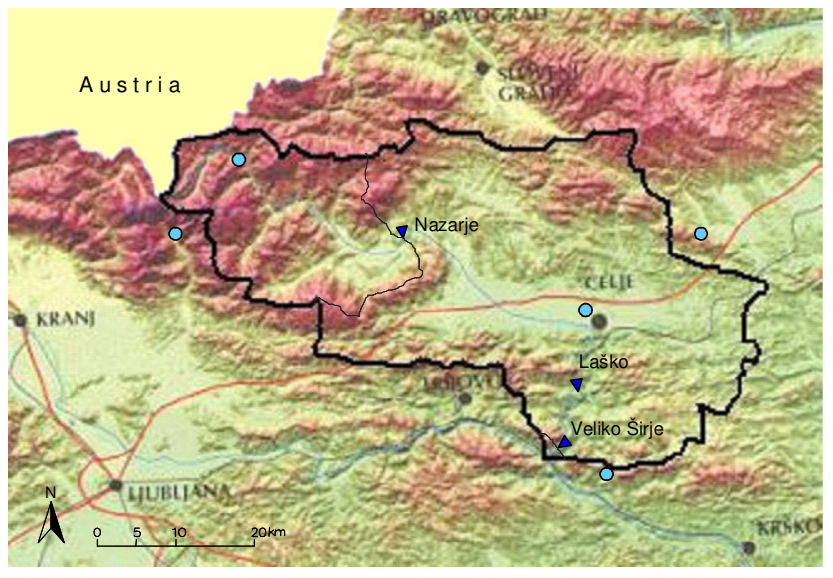

Fig. 1. Topography of the Savinja catchment with locations of main water gauging stations (triangles) and recording raingauges (dots).

Polajnar, 1998; Kobold and Sušnik, 2000). Regression models have been developed for predicting the peaks of flood waves, based on statistical analyses of historical high water peak discharges and precipitation events. In addition to regression models, the conceptual rainfall-runoff models are used for some basins. Among the fist, the HEC-1 model developed by the U.S. Army Corps of Engineers (Feldman, 1995) has been used for surface runoff simulation, but it is limited to simulations of single storm events. In the year 2003 the Swedish HBV model (Bergström, 1995) was tested for runoff simulation on the Savinja catchment as a research contribution in EFFS (European Flood Forecasting System) project (EFFS, 2004). The standard HBV model is normally operated on daily time step, but shorter time step can be possible to use if data are available (Bergström, 1995). We found no existing study of the model based on a shorter time step. To use the model for flash flood forecasting the version of HBV-96 (Lindström et al., 1997) was calibrated with time step of one hour.

\section{Study region}

The Savinja catchment with drainage area of $1848 \mathrm{~km}^{2}$ was used as a test basin for calibration and verification of the HBV model with time step of one hour (Fig. 1). The basin is situated in northeast of Slovenia. The length of the main watercourse is $101 \mathrm{~km}$ and is the largest tributary of the Sava River, main Balkan watercourse. The upper part of the catchment extends over the high mountainous area of the eastern Karavanke and the Savinja Alps with peaks higher than $2000 \mathrm{~m}$. They are built of carbonate rocks, more or less intensely karstified limestone and dolomite. Numerous major or minor springs indicate the great percolation of precipitation water into the underground. Lower down less permeable schists and tuffs occur, as well as sandstones and clays, which mainly compose the northern and southern hilly rims of the Celje basin. The most eastern part of the Savinja catchment is composed of impermeable Tertiary, Mesozoic and Paleozoic rocks. The altitudes of the plain area, in the middle reach of the Savinja, are between 200 and $400 \mathrm{~m}$. There is also a large alluvial plain with aquifer and high amount of ground water storage.

There are several soil types, i.e. mainly shallow soil on the limestone bedrock or very permeable alluvial coarse gravel formations. The catchment is mainly forested, especially in the mountainous and hilly areas. Forest covers nearly $60 \%$ of the catchment. The alluvial plains and the bottom of the river valleys are densely populated and used mainly for agriculture. The floods occur in that area each year and urban areas along the stream are in serious flood risk.

A complex topography of the Savinja catchment has a strong influence on meteorological phenomena in the region. The mean annual precipitation is about $2000 \mathrm{~mm}$ in the upper part and about $1300 \mathrm{~mm}$ in the lower part of the catchment. There is a lot of snowfall in high-altitude areas. Floods are caused mainly by heavy rainfall in autumn. The extensive precipitation region and heavy rainfall lasting more days can lead to a huge flood on the major part of the catchment. The last major floods occurred early in the month of November 1990 and November 1998 when several towns and villages along the river were flooded. In summer, the convective precipitation is characteristic for the catchment. The intensity of precipitation is non-uniform and this type of precipitation usually takes smaller regions with high intensity of precipitation and short duration of some minutes to a few hours. This can lead to local flash floods. Figure 2 shows the maximal monthly peak discharges in the period of the observation 1908-2000 for the Savinja River at Laško and the number of the highest annual occurrences by months for the same period (data for the period 1940-1945 are missing).

Floods in the Savinja catchment are short time duration of one or two days (Fig. 3). A lag time between rainfall and runoff is only a few hours. Flood in November 1990 is registered as the greatest flood happened on the Savinja catchment taking into account the period of observation. The highest recorded discharge at Laško water station was $1406 \mathrm{~m}^{3} / \mathrm{s}$ at that time, what is more than one hundred year return period of floods. Flooding also occurred on the Savinja tributaries which exceeded previously recorded flows (Kolbezen, 1991). In such environment, where small scale phenomena (small scale precipitation systems and torrential nature of rivers and flash floods) prevail, it is challenging to provide accurate hydrological prediction and warning systems. Timing of floods in short time basis is of high importance and essential for flood warnings. Hence the conceptual HBV-96 model was applied on the Savinja catchment with time resolution of one hour. 


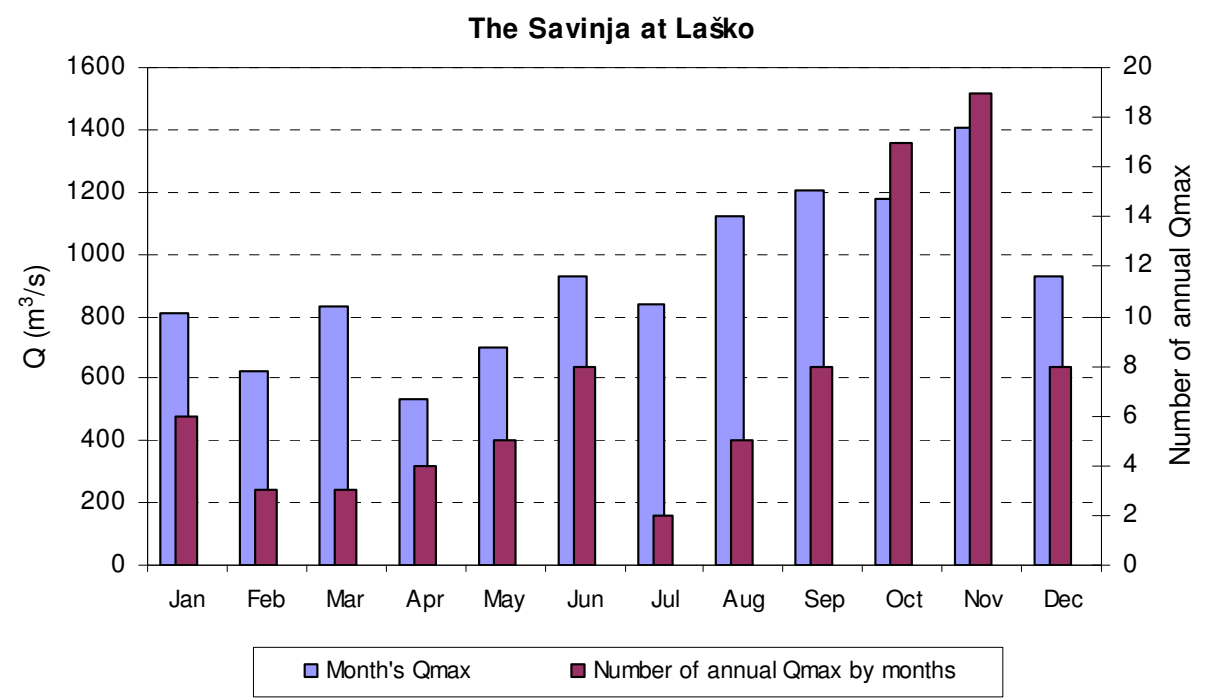

Fig. 2. The maximal monthly peak discharges Qmax and the number of the highest annual discharges by months in period $1908-2000$ for the Savinja River at Laško.

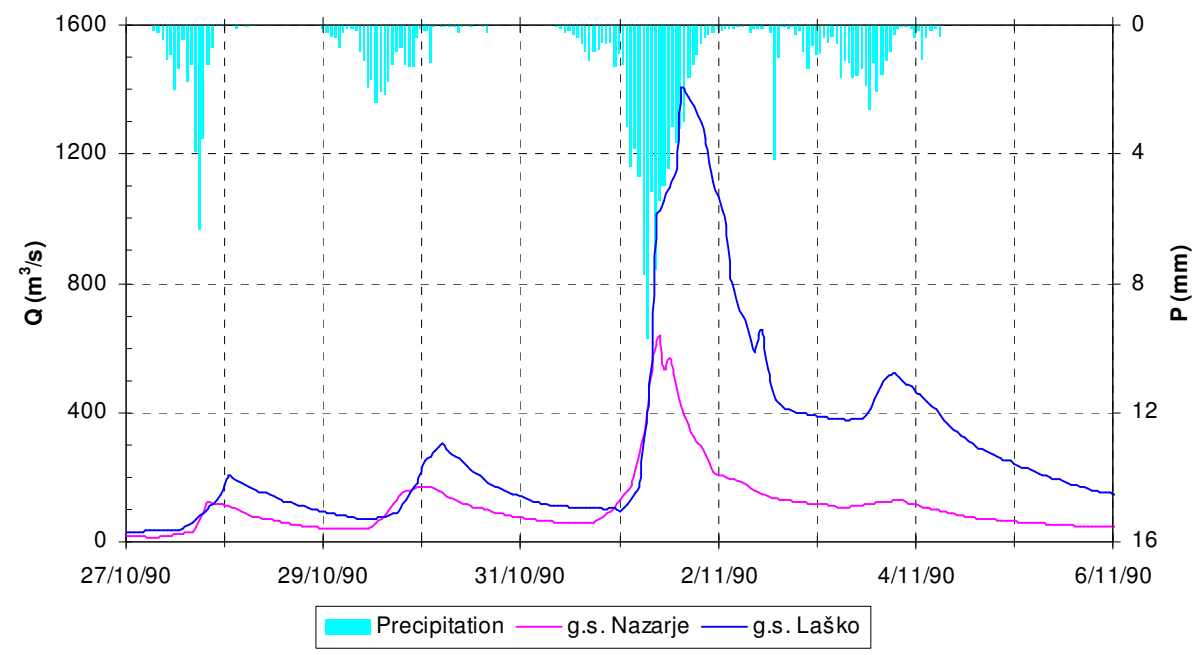

Fig. 3. Hydrographs and average areal hourly precipitation of the greatest flood in 1 November 1990 on the Savinja catchment.

\section{The HBV model}

The HBV model is a semi-distributed conceptual rainfallrunoff model for continuous calculation of runoff. It was developed by Swedish Meteorological and Hydrological Institute (Bergström, 1995; Lindström et al., 1997). The version of HBV-96 integrated into Integrated Hydrological Modelling System IHMS (IHMS, 1999) was used in the study. The model uses subbasins as primary hydrological units and within these an area-elevation distribution and a classification of land use (forest, open and lakes) can be made. The model consists of subroutines for snow accumulation and melt, soil moisture accounting procedure, routines for runoff generation and a routing procedure. Input data are precipitation, air temperature and potential evapotranspiration. Nor- mally, monthly standard values of potential evapotranspiration are sufficient. The principal output is discharge, however the other output variables relating to water balance components (precipitation, evapotranspiration, soil moisture, water storage) are available from the model (IHMS, 1999). Areal averages of the climatological data are computed separately for each subbasin by a simple weighting procedure where the weights are determined by climatological and topographical considerations or by some geometric method like the Thiessen polygons. The climatological input is further corrected for elevation above sea level by constant lapse rates (Bergström, 1995). Beside geographical characteristics of the catchment the model has a number of parameters, values of which are estimated by calibration. 
Table 1. Main characteristics of the Savinja sub-catchments.

\begin{tabular}{lcc}
\hline & Catchment to Nazarje & Catchment \\
\hline Area & $457.3 \mathrm{~km}^{2}$ & $1384.6 \mathrm{~km}^{2}$ \\
Min elevation & $340 \mathrm{~m}$ a.s.l. & $230 \mathrm{~m}$ a.s.l. \\
Max elevation & $2340 \mathrm{~m}$ a.s.l. & $1560 \mathrm{~m}$ a.s.l. \\
Mean elevation & $940 \mathrm{~m}$ a.s.l. & $490 \mathrm{~m}$ a.s.l. \\
Mean catchment slope & $33 \%$ & $16 \%$ \\
Forests & $324.7 \mathrm{~km}^{2}(71 \%)$ & $724.3 \mathrm{~km}^{2}(52 \%)$ \\
Agriculture areas & $109.5 \mathrm{~km}^{2}(24 \%)$ & $607.3 \mathrm{~km}^{2}(44 \%)$ \\
Other land use & $23.1 \mathrm{~km}^{2}(5 \%)$ & $53.0 \mathrm{~km}^{2}(4 \%)$ \\
\hline
\end{tabular}
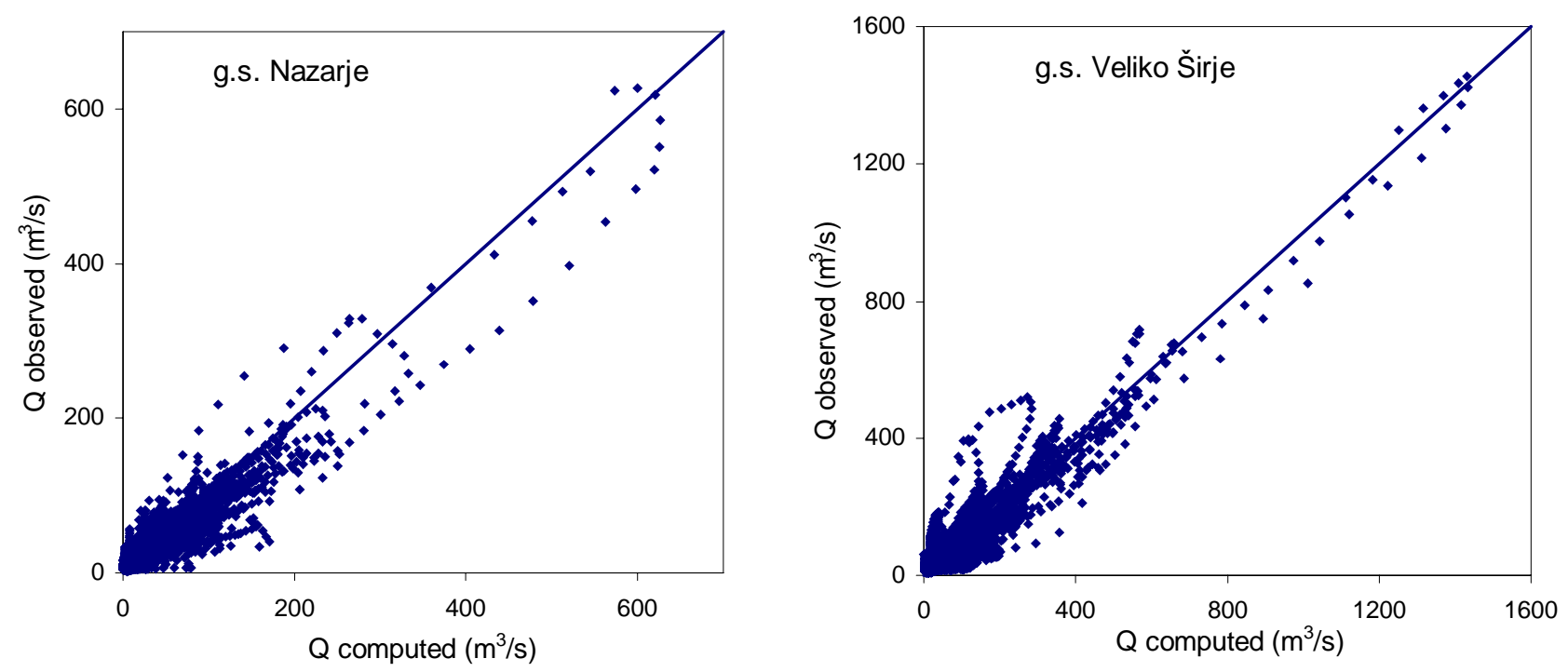

Fig. 4. Comparison of computed and observed discharges for the period 1998-1999.

\subsection{Sub-catchment characteristics}

The Savinja catchment was divided into two sub-catchments regarding the water gauging stations Nazarje and Veliko Sirje (Fig. 1). The catchment to Nazarje collects water from $457.3 \mathrm{~km}^{2}$ (upper sub-catchment), and remaining part to Veliko Širje, which is close to the outlet, from $1384.6 \mathrm{~km}^{2}$ (lower sub-catchment). The average elevation of the upper sub-catchment is $940 \mathrm{~m}$ a.s.1., ranges from 340 to $2340 \mathrm{~m}$ a.s.1., and $490 \mathrm{~m}$ a.s.l. of the lower one, ranges from 230 to $1560 \mathrm{~m}$ a.s.l. The mean catchment slope is $33 \%$ for the upper sub-catchment and $16 \%$ for the lower one. The catchment is mainly forested; the rest areas are used mainly for agriculture. The main characteristics of the Savinja subcatchments are summarized in Table 1.

The study catchment is equipped with 23 meteorological stations, but among them only five stations are recording raingauges from which the hourly data are available. Two recording raingauges are located inside the catchment and three others around it (Fig. 1). The data of recording raingauges were used in the calibration of the hourly HBV model. In comparison with the HEC-1 model (Feldman, 1995) in which both type of precipitation stations (recording and non-recording) are included in simulation irrespective of time step, the HBV model supports only the data referring to the chosen time step. Time-series input data in the HBV model have to be the same as the computation time interval.

\subsection{Model calibration}

The hourly values of hydrological and meteorological data for the period 1998-1999 were used to calibrate the HBV-96 model for the Savinja catchment with the time step of one hour. While 10 years of daily data are normally used for the calibration of HBV model (Bergström, 1995), we used correspondingly shorter period of data for shorter time step. Monthly values of evapotranspiration were available from one meteorological station in the cathment (station located 


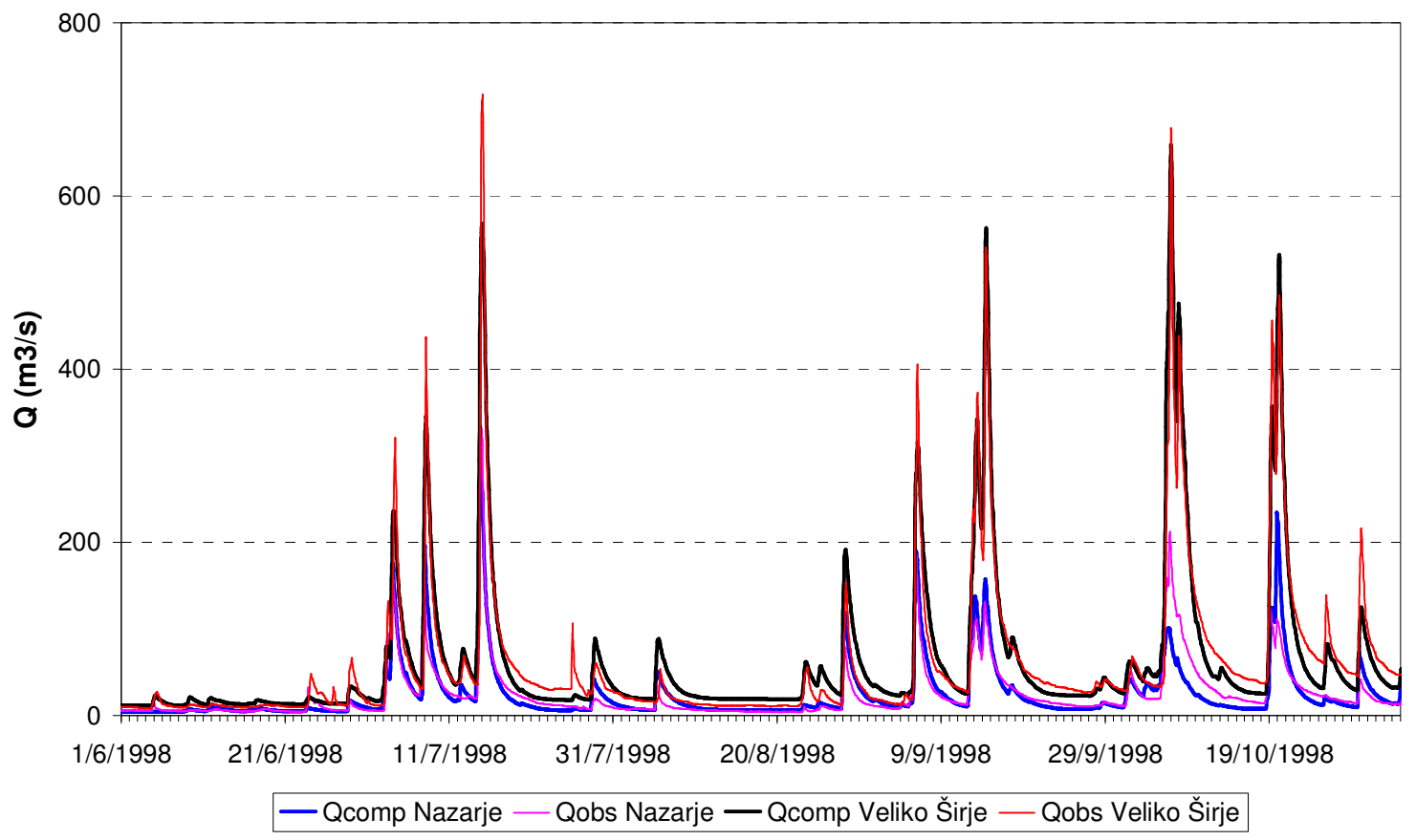

Fig. 5. A comparison of computed and observed hourly discharges for a part of year 1998.

Table 2. Calibration results of hourly HBV-96 model for the Savinja catchment.

\begin{tabular}{lcccc}
\hline $\begin{array}{l}\text { CALIBRATION } \\
\text { (period 1998-1999) }\end{array}$ & $\begin{array}{c}\text { Nash and Sutcliffe criterion } \\
\mathrm{R}^{2}\end{array}$ & $\begin{array}{c}\text { Regression coefficient } \\
\mathrm{r}^{2}\end{array}$ & $\begin{array}{c}\text { Mean absolute error } \\
\left(\mathrm{m}^{3} / \mathrm{s}\right)\end{array}$ & $\begin{array}{c}\text { Absolute standard deviation } \\
\left(\mathrm{m}^{3} / \mathrm{s}\right)\end{array}$ \\
\hline g.s. Nazarje & 0.78 & 0.8134 & 6.74 & 10.4 \\
g.s. Veliko Širje & 0.86 & 0.8634 & 15.30 & 20.2 \\
\hline
\end{tabular}

in the middle reach of the Savinja in Fig. 1). Andréassian et al. (2004) and Oudin et al. (2005a, b) have shown that very simple assumptions of areal potential evapotranspiration as input in the catchment model (the same average for all subcatchments) yield the similar results as improved estimates of areal potential evapotranspiration. According to their conclusions we supposed that the estimate of areal evapotranspiration from one station did not have a significant influence on the efficiency of the model. The weights of raingauges in the model were defined by the method of Thiessen polygons.

The agreement between observed and computed runoff was evaluated by three main criteria of fit (IHMS, 1999): (a) visual inspection of the computed and observed hydrographs, (b) a continuous plot of the accumulated difference between the computed and the observed hydrographs expressed as

Accdiff $=\sum\left(Q_{\mathrm{com}}-Q_{\mathrm{obs}}\right) \cdot C_{t}$

where $Q_{\text {com }}$ is computed discharge, $Q_{\text {obs }}$ observed discharge and $C_{t}$ a constant transforming to mm over the basin in time t, and (c) Nash and Sutcliffe efficiency criterion (Nash and Sut- cliffe, 1970) which is commonly used in hydrological modelling

$$
R^{2}=1-\frac{\sum\left(Q_{\mathrm{com}}-Q_{\mathrm{obs}}\right)^{2}}{\sum\left(Q_{\mathrm{obs}}-\overline{Q_{\mathrm{obs}}}\right)^{2}}
$$

A perfect fit would give a value of $R^{2}=1$, but in practice the value above 0.8 means good fit of simulated and measured hydrographs (IHMS, 1999). For the Savinja catchment, the $R^{2}$ value of 0.78 for g.s. Nazarje and 0.86 for g.s. Veliko Širje was reached by the calibration of hourly data (Fig. 4, Table 2). The criterion of $R^{2}$ is smaller for upper subcatchment, which is mostly mountainous with strong orographic influences. The distribution of precipitation in upper part can vary a lot and areal precipitation over a catchment area is not well defined with available recording raingauges. For the lower sub-catchment the variability of precipitation is not so high and the simulated discharges on the outlet of the basin fit with measured ones quite good. However, the calibration of the model is quite satisfactory (Fig. 5). 
Supposing that the parameters of the model were well defined, the uncertainty of simulated runoff is mainly the result of precipitation uncertainty associated with the average basin precipitation and is higher for mountainous part of the catchment. Therefore the analysis of the influence of number of raingauges on the estimation of mean areal precipitation was performed.

3.3 The influence of number of raingauges on areal precipitation estimation

The HBV-96 model calculates the areal precipitation with weights which were defined by the method of Thiessen polygons. This method is still the most frequent method used in hydrological practice although it is not suitable for areas with complex topography (Bonacci, 1994). To find out the impact of the number of raingauges on the estimation of mean areal precipitation in the HBV-96 model, the daily areal precipitation was computed with two different sets of raingauges. In the first case all raingauges on the catchment were used in the estimation of daily areal precipitation and in the second one only recording raingauges were included. In both cases, the weights were defined by the method of Thiessen polygons (Fig. 6). The period of 1998-2002 was taken in the study. There was made an assumption that mean areal precipitation calculated in the first case considering all raingauges was accurate and absolute and relative deviations of areal precipitation were investigated for the second case using only recording raingauges (Fig. 7).

The mean areal precipitation estimated from five recording raingauges can differ a lot from mean areal precipitation estimated from all raingauges on the catchment (Fig. 7). The absolute deviations are mainly between -10 and $10 \mathrm{~mm}$ for both sub-catchments, but the points are more scattered for the upper mountainous part, for whose the deviations can also be much greater, especially by higher amount of precipitation. The relative errors can exceed $100 \%$ by estimation of mean areal precipitation below $3 \mathrm{~mm}$ for both sub-catchments (Fig. 7). On the diagrams in Fig. 7 showing the relative deviation, only the values for precipitation above $3 \mathrm{~mm}$ are presented. The relative errors are decreasing by the amount of precipitation rising. High waters and floods on the Savinja catchment usually occur by precipitation above $40 \mathrm{~mm}$ over the catchment area and considering precipitation above this value, the average relative error is about $15 \%$ for upper sub-catchment with standard deviation of $14.5 \%$ and $5.5 \%$ for lower sub-catchment with standard deviation of $3.2 \%$. Taking into account only recording raingauges on the Savinja catchment and method of Thiessen polygons, very large errors of estimated mean areal precipitation can be made. Incorrect estimation of precipitation further leads to wrong estimation of simulated discharges. Rainfall-runoff models are sensitive to precipitation input (Kobold and Sušelj, 2005) and finding out the influence of precipitation error to simulated runoff, the sensitivity of $\mathrm{HBV}$ model to rainfall error has been performed.

\section{The sensitivity of the HBV model to rainfall}

A peak discharge and time of the peak are the most important information in flood event. The uncertainty of simulated river discharge is mainly the result of precipitation uncertainty associated with the average basin precipitation. Simulation of runoff can give an incorrect result if precipitation is charged with an error what is common not only in estimation of precipitation from raingauges, but also in precipitation forecast (Sattler, 2002; Sattler and Feddersen, 2003; Kobold and Sušelj, 2005).

To find out the measure of runoff uncertainty regarding to precipitation error, the analysis of sensitivity of the HBV-96 model to rainfall error has been performed. The period from beginning of August 1998 to the end of November 1998 was taken in analysis. Precipitation caused high water events in that period (14 events), was multiplied by different coefficients from 0.4 to 1.3 , representing an error in precipitation. The simulations of events were made by the calibrated HBV96 model and performed independently from one to another. That means that only analysed event was charged with an error in precipitation, while the other circumstances remained unchanged.

Only peak discharges were analysed in the study ignoring time of the peak. Actually the simulated peaks mostly coincide with measured ones (Fig. 5). Dimensionless coefficients were calculated for all analysed high water events for water stations Nazarje and Veliko Širje (Fig. 8), expressed as the ratio of peak discharges calculated by weighted measured precipitation and measured precipitation

$k_{\mathrm{Qpeak}}^{i, k_{P}}=\frac{Q_{\mathrm{peak}}^{i, k_{P}}}{Q_{\text {peak }}^{i, P}}$

where $i$ means high water event, $k_{P}$ weighted precipitation by the coefficient in the range $[0.4,1.3]$ and $P$ measured precipitation for the event $i$. The range of peak coefficients is greater in events with low soil moisture, especially in the events occurred after a long dry period when precipitation losses can be very high.

The interdependence between coefficients of peak discharges and coefficients of precipitation is shown in Fig. 9 for both water gauging stations. The coefficients of both stations are mostly covered. The diagram shows that an error in precipitation leads to much greater error in peak discharge. The relationship is polynomial and is independent of catchment area. The following polynomial formulae are obtained from Fig. 9:

$$
k_{\text {Qpeak }}=0.65 \cdot k_{P}^{2}+0.33 \cdot k_{P}+0.02
$$



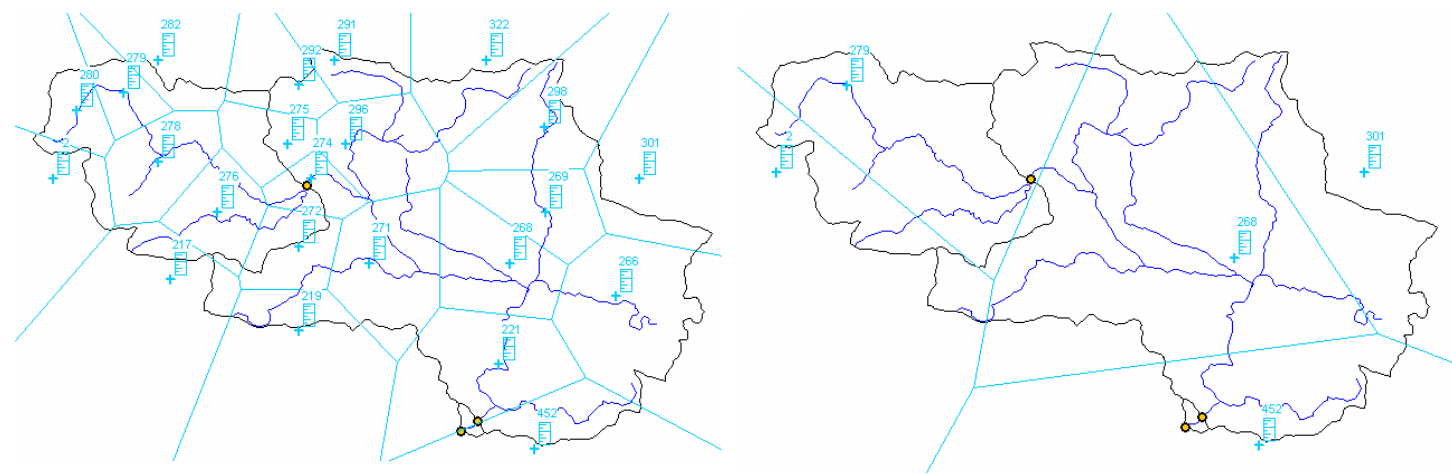

Fig. 6. Raingauges networks and Thiessen polygons on the Savinja catchment.
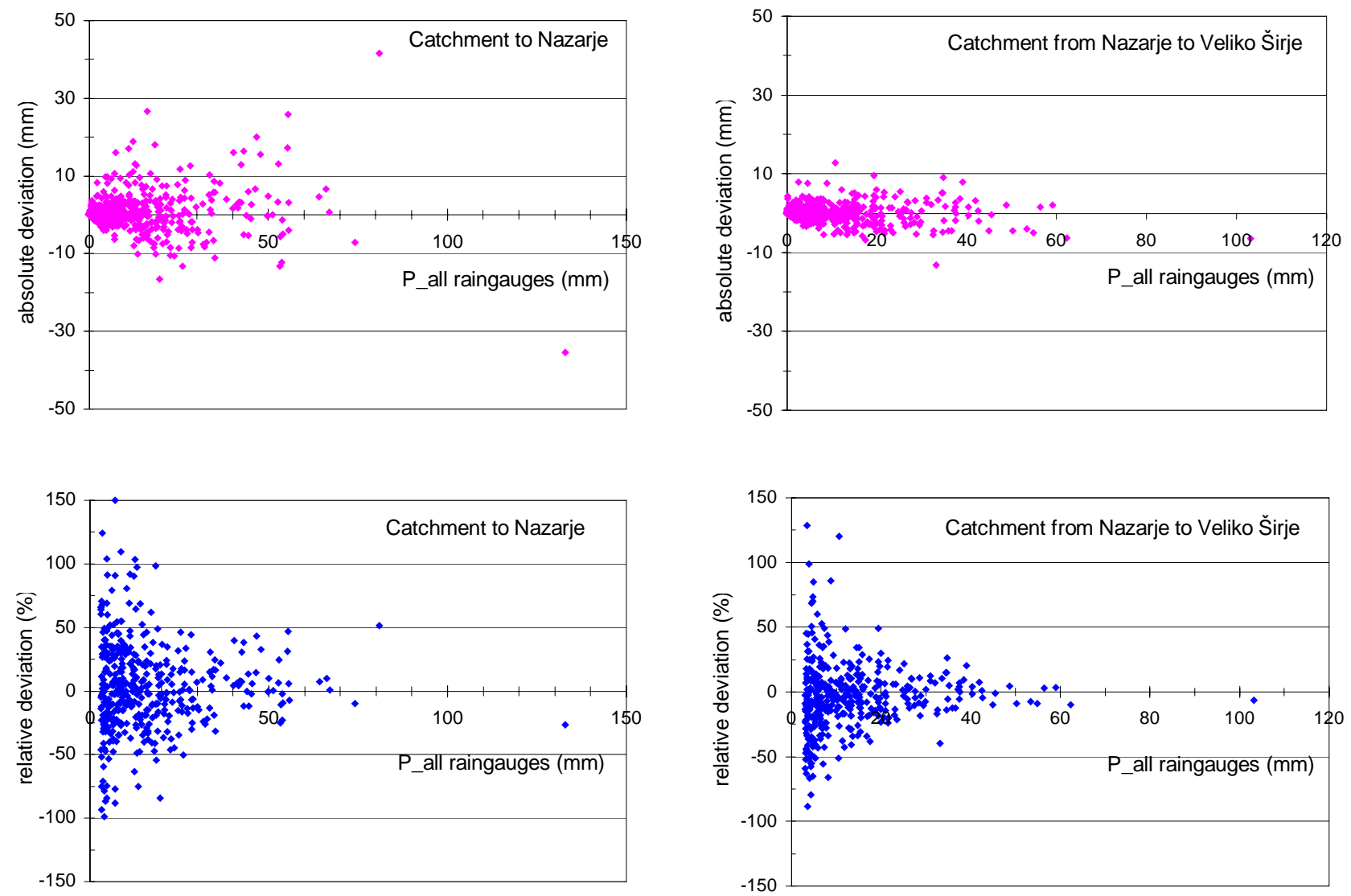

Fig. 7. Relative and absolute deviations of mean daily areal precipitation taking into account five recording raingauges in comparison with all raingauges located on the Savinja catchment.

for gauging station Nazarje with regression coefficient $r$ of 0.9950 , and

$k_{\text {Qpeak }}=0.67 \cdot k_{P}^{2}+0.30 \cdot k_{P}+0.02$

for gauging station Veliko Širje with regression coefficient $r$ of $0.9976 . k_{\text {Qpeak }}$ is the coefficient of peak discharge and $k_{P}$ coefficient of precipitation. There are almost no differences in equations.

Performed analysis has shown that an error in rainfall, which is input into the rainfall-runoff model, can result in great runoff deviation. If precipitation is overestimated for about $10 \%$, the simulated runoff is overestimated for about $17 \%$. The mean values of coefficients, standard deviations 

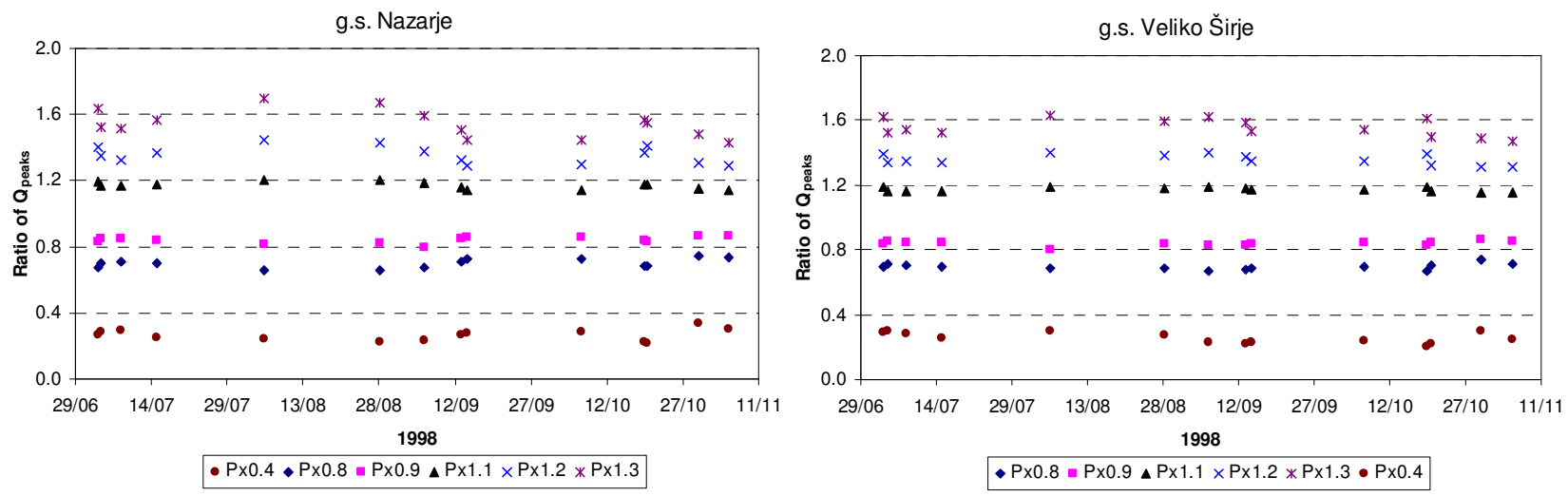

Fig. 8. Coefficients of peak discharges regarding to an error in precipitation.

Table 3. Mean values of coefficients of peak discharges, standard deviations and standard errors resulting from an error in precipitation.

\begin{tabular}{ccccccc}
\hline coefficient of $P_{\text {event }}$ & \multicolumn{3}{c}{ g.s. Nazarje } & \multicolumn{3}{c}{ g.s. Veliko Širje } \\
mean coeff. & $\begin{array}{c}\text { standard } \\
\text { of Q Qeak }\end{array}$ & standard & $\begin{array}{c}\text { mean coeff. } \\
\text { deviation }\end{array}$ & error & standard & standard \\
deviation & error \\
\hline 0.4 & 0.27 & 0.0355 & 0.0095 & 0.26 & 0.0353 & 0.0094 \\
0.8 & 0.70 & 0.0270 & 0.0070 & 0.70 & 0.0196 & 0.0052 \\
0.9 & 0.84 & 0.0200 & 0.0053 & 0.84 & 0.0156 & 0.0042 \\
1.1 & 1.17 & 0.0217 & 0.0058 & 1.17 & 0.0140 & 0.0037 \\
1.2 & 1.36 & 0.0512 & 0.0137 & 1.36 & 0.0325 & 0.0087 \\
1.3 & 1.54 & 0.0836 & 0.0223 & 1.56 & 0.0549 & 0.0147 \\
\hline
\end{tabular}

and standard errors are given for both water stations in Table 3. Standard deviation and standard error increase with an error in precipitation. While the mean coefficient of peak discharge is almost the same for water stations, the standard deviations and standard errors are greater for Nazarje (upper mountainous sub-catchment). The average percentage errors are shown in Fig. 10.

Regarding to results of performed analysis it is very important to assure the accurate precipitation input whether from raingauges or other sources (radar measurements, meteorological forecast). The need to accurately describe temporal and spatial rainfall variability is of crucial importance for modelling especially small catchment response what have also been pointed out by Faurès et al. (1995) and Bell and Moore (2000).

\section{Operational runs of $\mathrm{HBV}$ model}

Showing the applicability of usage the hourly HBV-96 model calibrated for the Savinja catchment, the model was tested for operational short-term forecast in the year 2004. In that case the model was run using measured input data of precipitation and temperature for a period before forecast and forecasted precipitation and temperature for a period of forecast. The forecasts of mesoscale ALADIN/SI model covering Slovenia (Vrhovec et al., 1998) were used in operational runs. The forecasts of meteorological parameters of the ALADIN/SI model are made in spatial resolution of about $9.5 \mathrm{~km}$ and are available up to $48 \mathrm{~h}$ ahead. The model is operational and run twice a day.

The results of simulations for the period from end of February to August 2004 are presented in Fig. 11. The comparison of simulated and observed discharges is separated on two parts: forecasts for the first day and forecasts for the second day. The performed analysis has shown that the forecasts are better for the first day and they are acceptable for water station of Veliko Širje close to the outlet of the catchment. The correlation coefficient $r$ is 0.93 for the forecasts of first day and is 0.82 for the forecasts of second day. Very poor correlation is observed for the upper part of the catchment at Nazarje. The correlation coefficient $r$ is 0.73 for the forecasts of first day and below 0.50 for the forecasts of second day. The reason for that could be in uncertainty of ALADIN/SI forecasted precipitation for mountainous region. Additional analyses should be made to show the reliability of ALADIN/SI precipitation forecasts. However, the HBV model is suitable tool for flash flood forecasting. The 


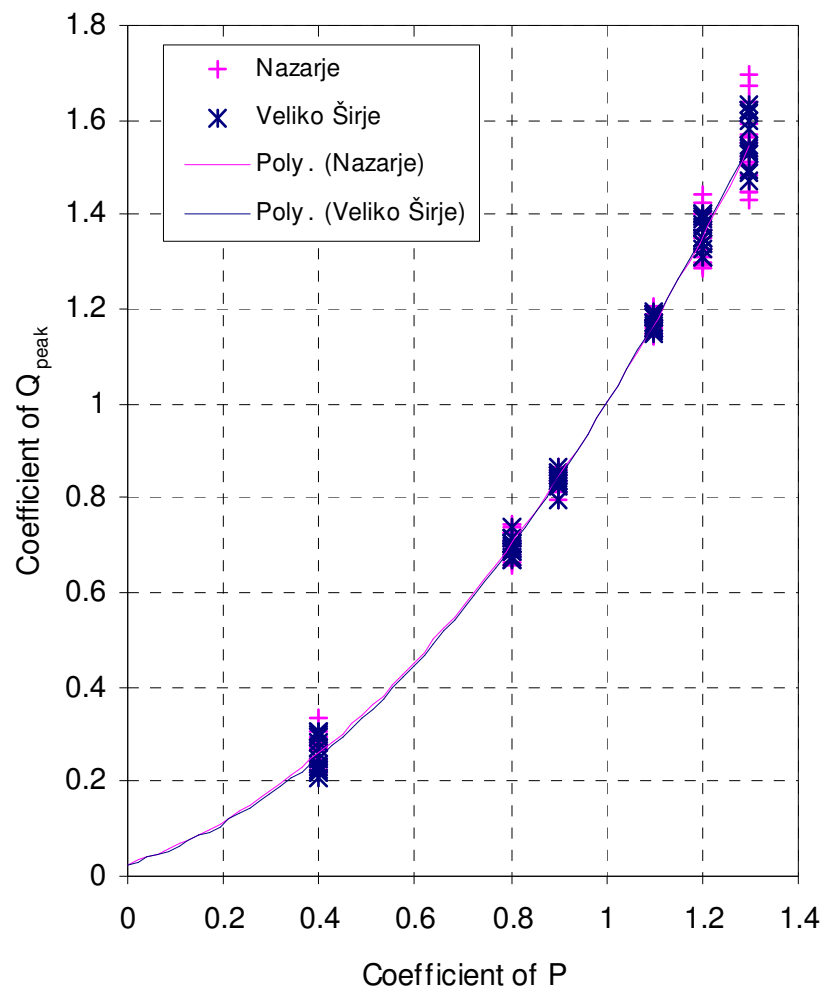

Fig. 9. Deviation of peak discharges taking into account an error in precipitation, both expressed by coefficients.

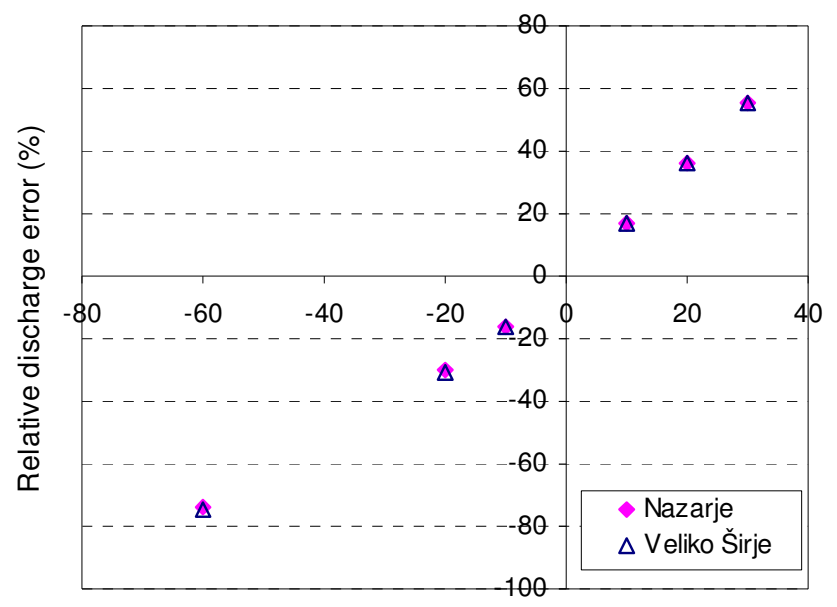

Relative precipitation error (\%)

Fig. 10. The influence of precipitation error on peak discharge error.

accurate input data are preliminary condition to use it for hydrological applications.

\section{Conclusions}

The HBV-96 model enables the simulations of flash floods and can be used in pre-warning systems. The calibration of
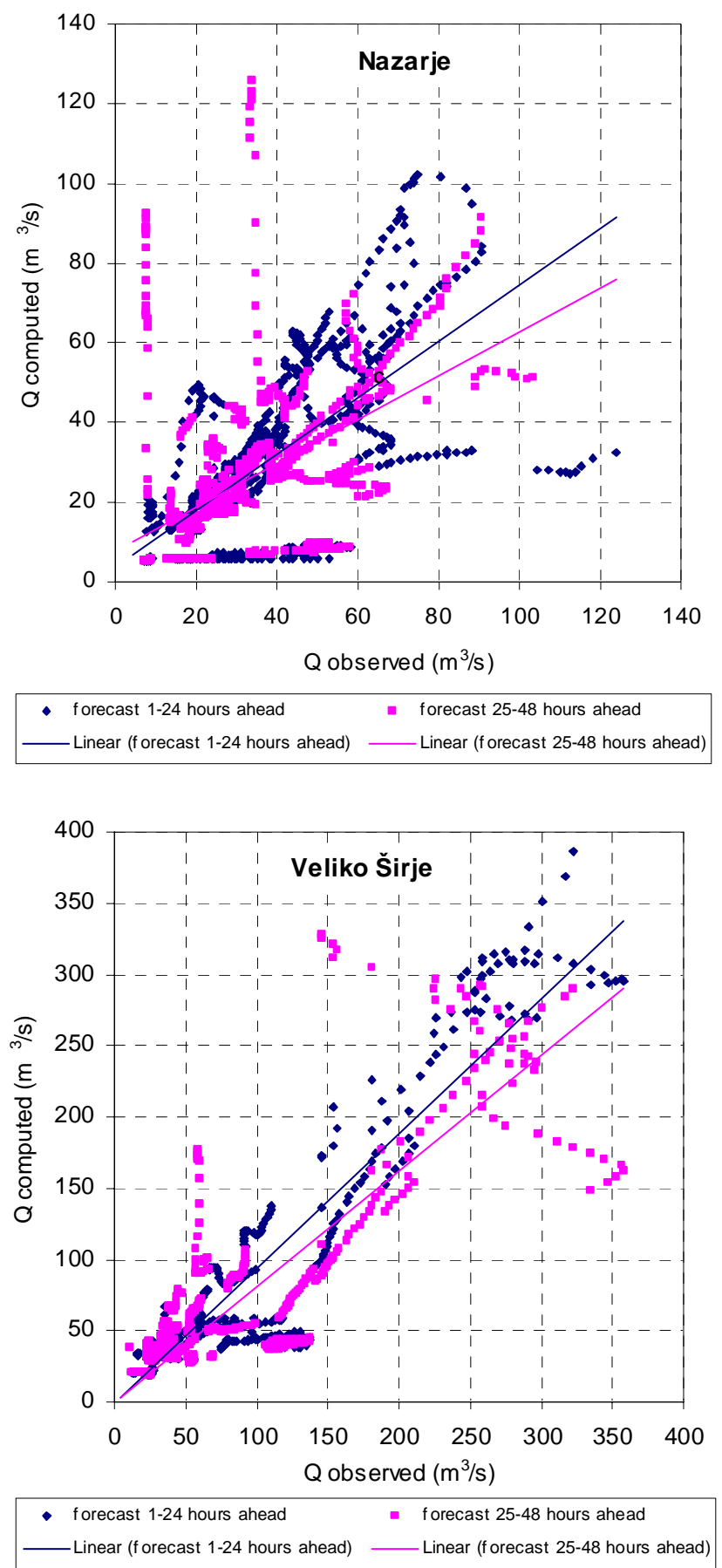

Fig. 11. The comparison of simulated and observed discharges of operational HBV-96 runs on the Savinja catchment for the period from February to August 2004.

the model for the Savinja catchment with time step of one hour is quite satisfactory for the whole catchment as well for the smaller mountainous part up to Nazarje. While the Nash and Sutcliffe efficiency criterion was achieved representing 
good fit of the computed and observed hydrographs by calibration of the model, the main obstacle in modelling with short time step is still the lack of data needed for model calibration and later for operational use.

The uncertainty of simulated runoff is mainly the result of precipitation uncertainty associated with the average basin precipitation. The significant problem with raingauge network is the inability to determine the areal patterns of precipitation or to identify the heaviest amounts. The accurate estimation of mean areal precipitation depends on the number of raingauges on the catchment. Especially shorter time intervals under one day and small catchments with complex orography and high variability of precipitation are usually not covered by enough recording raingauges to assure the accurate areal precipitation. On the other hand, the method of Thiessen polygons is not suitable for estimation of mean areal precipitation on areas with complex topography and small number of stations. Some other methods should be tested for calculation of areal precipitation (Bonacci, 1994). Anyway, the great source of data is radar measurements which could be used as input into hydrological models for flash flood forecasting. First analyses performed for the Savinja catchment with available radar data have shown the need by correction of radar data with ground rainfall measurements (Kobold and Zgonc, 1998), but it has not been done yet.

The sensitivity of HBV model to error in precipitation input shows that an error in rainfall causes larger error in simulated discharge. For example, an error of $10 \%$ in the amount of overestimated precipitation overestimates the peak of flood wave for $17 \%$. The relationship between the errors in rainfall amounts and peak discharges is polynomial. These results are important to understand the model's outputs by simulations with measured data as well as by operational runs using the predicted precipitation as input. With the known deviation of estimated or predicted precipitation from the measured one the simulated discharge could be interpreted more precisely. Uncertainty of precipitation forecast is the main reason for limited use of rainfall-runoff models and it is the primary source of uncertainty in flood forecasting (Nandakumar and Main, 1997; Krzysztofowicz, 2001; Collischonn et al., 2005). The accurate precipitation with quantification of uncertainty of predicted precipitation is necessary to increase the reliability of hydrological forecasts and can aid to give advance warning of potential flooding.

Acknowledgements. The authors are very grateful to the anonymous reviewers for their very useful comments.

Edited by: L. Ferraris

Reviewed by: two referees

\section{References}

Andréassian, V., Perrin, C., and Michel, C.: Impact of imperfect potential evapotranspiration knowledge on the efficiency and parameters of watershed models, J. Hydrol., 286, 19- 35, 2004.

Askew, A. J.: Real time intercomparison of hydrological models, in: New Directions for Surface Water Modelling, edited by: Kavas, M. L., IAHS Pub No. 181, 125-132, 1989.

Bell, V. A. and Moore, R. J.: The sensitivity of catchment runoff models to rainfall data at different spatial scales, Hydrol. Earth Syst. Sci., 4, 653-667, 2000.

Bergström, S.: The HBV model, in: Computer Models of Watershed Hydrology, edited by: Sing, V. P., 443-476, Water Resour Publication, Colorado, USA, 1995.

Beven, K.: Rainfall-runoff modelling. The Primer, John Wiley \& Sons, Ltd., England, 2001.

Bonacci, O.: Oborine glavna ulazna velicina u hidrološki ciklus, GEING Split, (in Croatian), 1994.

Collischonn, W., Haas, R., Andreolli, I., and Tucci, C. E. M.: Forecasting River Uruguay flow using rainfall forecasts from a regional weather-prediction model, J. Hydrol., 305, 87-98, 2005.

EFFS: A European Flood Forecasting System EFFS. Full Report, edited by: Gouweleeuw, B., Reggiani, P., and de Roo, A., Contract no. EVG1-CT-1999-00011, WL Delft Hydraulics, Netherlands, 2004.

Faurès, J. N., Goodrich, D. C., Woolhiser, D. A., and Sorooshian, S.: Impact of small-scale spatial rainfall variability on runoff modeling, J. Hydrol., 173, 309-326, 1995.

Feldman, A. D.: HEC-1 Flood Hydrograph Package, in: Computer Models of Watershed Hydrology, edited by: Sing, V. P., 119-150, Water Resour. Publication, Colorado,USA, 1995.

IHMS: Integrated Hydrological Modelling System. Manual, Version 4.5. Swedish Meteorological and Hydrological Institute, Norrköping, Sweden, 1999.

Job, D., Humbel, M., Müller, D., and Sagna, J.: Flood estimation Buenz Valley, Switzerland. Practical use of rainfall-runoff models, in: Proceedings of International Conference on Flood Estimation, CHR Report II-17, Berne, Switzerland, 519-527, 2002.

Kobold, M. and Sušelj, K.: Precipitation forecasts and their uncertainty as input into hydrological models, Hydrol. Earth Syst. Sci., 9, 322-332, 2005

Kobold, M. and Sušnik, M.: Watershed modelling and surface runoff simulation, in: Tagungspublikation Internationales Symposion INTERPRAEVENT 2000, Villach, Österreich, vol. 2, 329-338, 2000.

Kobold, M. and Zgonc, A.: The accuracy of the radar-estimated areal hourly rainfall, COST-75, Advanced weather radar system, International seminar, Locarno, Switzerland, Proceedings, 179186, 1998.

Kokkonen, T. S. and Jakeman, A. J.: A comparison of metric and conceptual approaches in rainfall-runoff modeling and its implications, American Geophsical Union (AGU), Reprinted from Water Resour. Res., 37, 9, 2345-2352, 2001.

Kolbezen, M.: Flooding in Slovenia on November 1, 1990, Ujma 5 , Ljubljana, 16-18, 1991.

Krzysztofowicz, R.: The case of probabilistic forecasting in hydrology, J. Hydrol., 249, 2-9, 2001.

Lindström, G., Johansson, B., Persson, M., Gardelin, M., and Bergström, S.: Development and test of the distributed HBV-96 hydrological model, J. Hydrol., 201, 272-288, 1997. 
Nandakumar, N. and Mein, R. G.: Uncertainty in rainfall-runoff model simulations and the implications for predicting the hydrologic effects of land-use change, J. Hydrol., 192, 211-232, 1997.

Nash, J. E. and Sutcliffe, J. V.: River flow forecasting through conceptual models. Part I. A discussion of principles, J. Hydrol., 10, 282-290, 1970.

Oudin, L., Michel, C., and Anctil, F.: Which potential evapotranspiration input for a lumped rainfall-runoff model? Part 1-Can rainfall-runoff models effectively handle detailed potential evapotranspiration inputs?, J. Hydrol., 303, 275-289, 2005 a.

Oudin, L., Hervieu, F., Michel, C., Perrin, C., Andréassian, V., Anctil, F., and Loumagne, C.: Which potential evapotranspiration input for a lumped rainfall-runoff model? Part 2-Towards a simple and efficient potential evapotranspiration model for rainfallrunoff modelling, J. Hydrol., 303, 290-306, 2005 b.

Perrin, C., Michel, C., and Andréassian, V.: Does a large number of parameters enhance model performance? Comparative assessment of common catchment model structures on 429 catchments, J. Hydrol., 242, 275-301, 2001.

Sattler, K.: Precipitation hindcast of historical flood events. An European Flood Forecasting System, Deliverable Report 6.1, Contract no. EVG1-CT-1999-00011, WL Delft Hydraulics, Netherlands, 2002.
Sattler, K. and Feddersen, H.: Study on the treatment of uncertainties in limited-area NWP rainfall using different ensemble approaches. An European Flood Forecasting System, Deliverable Report 6.2, Contract no. EVG1-CT-1999-00011, WL Delft Hydraulics, Netherlands, 2003.

Singh, V. P.: Computer Models of Watershed Hydrology, Water Resour. Publication, Colorado, USA, 1995.

Smith, K. and Ward, R.: Floods, Physical Processes and Human Impact, John Wiley \& Sons Ltd, Chichester, England, 1998.

Sušnik, M. and Polajnar, J.: Simple hydrological forecasting models: operational experience. Proceedings of XIXth Conference of the Danube Countries, Osijek, Croatia, 31-36, 1998.

Vrhovec, T., Žagar, M., Brilly, M., and Šraj, M.: Forecasting of intense precipitation using the ALADIN-SI model and modelling of the runoff, in: Proc. the 17th Goljevšek Memorial Day, Acta hydrotechnica 16/23, Ljubljana, Slovenia, 71-84, 1998.

WMO: Intercomparison of conceptual models used in operational hydrological forecasting, Operational Hydrology Report No. 7, Geneva, Switzerland, 1975.

WMO: Simulated real-time intercomparison of hydrological models, Operational Hydrology Report No. 38, Geneva, Switzerland, 1992.

WMO: Guide to hydrological practices, WMO-No. 168, Fifth edition, Geneva, Switzerland, 1994. 